\title{
COMPETENCE ASSESSMENT: A MEASUREMENT SYSTEM FOR THE SUBJECT "APPLIED ANALYTICAL CHEMISTRY" OF THE PHARMACY DEGREE
}

\begin{abstract}
The current university environment is characterised by the implementation of an education system focused on competence-based learning. The present study has concentrated on the subject Applied Analytical Chemistry of the Pharmacy Degree and has made it possible to clearly establish the specific competences of the subject, based on levels of acquisition, as well as to design a system of assessment, based on the use of rubrics, which provides the corresponding equivalences in the grading system currently used in the university. This new form of assessment allows the teacher to know where there are gaps in student learning, and this information can be subsequently used to prioritize the training of those skills. The implementation of these rubrics has made it possible to obtain relevant information related to the students' acquisition of competences.
\end{abstract}

Keywords: Competences; Applied Analytical Chemistry; Pharmacy Degree; Rubric

\section{EVALUACIÓN DE LAS COMPETENCIAS: UN SISTEMA DE MEDICIÓN PARA LA ASIGNATURA "QUÍMICA ANALÍTICA APLICADA" DEL GRADO EN FARMACIA}

\begin{abstract}
Resumen
El entorno universitario actual se caracteriza por la implementación de un sistema educativo centrado en el aprendizaje basado en competencias. Este trabajo se centra en la asignatura de Química Analítica Aplicada del Grado en Farmacia y trata de establecer claramente las competencias específicas de la asignatura, en función de los niveles de adquisición, así como diseñar un sistema de evaluación, basado en el uso de rúbricas, proporcionando las equivalencias correspondientes en el sistema de calificación actualmente utilizado en la Universidad. Esta nueva forma de evaluación permite al docente saber dónde hay vacíos en el aprendizaje de los estudiantes, de modo que esta información puede usarse posteriormente para priorizar el entrenamiento de esas habilidades. La implementación de estas rúbricas ha permitido obtener información relevante relacionada con la adquisición de competencias de los estudiantes.
\end{abstract}

Palabras clave: Competencias; Química Analítica Aplicada; Grado en Farmacia; Rúbricas

Autores: Ma Teresa Morales ${ }^{1}$, Inmaculada Romero ${ }^{1}$, Dolores Hernanz ${ }^{1}$, Ma Ángeles Herrador ${ }^{1}, M$ a Teresa Montaña ${ }^{1}$, Guillermina Galán ${ }^{1}$, Ma José Navas ${ }^{1}$, Ana Ma Jiménez ${ }^{1}$, Ma Mar Orta ${ }^{1}$, Diego L. García-González ${ }^{1}$, Julia Martín ${ }^{2}$, Agustín G. Asuero ${ }^{1}$

\footnotetext{
Department of Analytical Chemistry, Faculty of Pharmacy, University of Seville.

2 Department of Analytical Chemistry, Escuela Politécnica Superior, University of Seville.
} 


\section{COMPETENCE ASSESSMENT: A MEASUREMENT SYSTEM FOR THE SUBJECT "APPLIED ANALYTICAL CHEMISTRY" OF THE PHARMACY DEGREE}

\section{Introduction}

$\mathrm{n}$ recent years, the concept of education has changed significantly due to the process of European convergence. On the one hand, this has meant that the university teachers of various countries have had to orient the curricula of the different degrees towards external similarities and, on the other hand, there has been a rethinking of the teachinglearning process towards a student-centred learning approach. This implies that the activities of the students have to be planned in relation to the competences that they are going to put into practice in real professional settings (Poloyac et al., 2011). This new method of teaching requires carrying out a new form of assessment, because if the proposed training model is competence-based it is, therefore, necessary to have competence-based assessment. This is not solely a question of techniques, but also involves a cultural change in the concept of assessment and of its purpose.

At any educational level, issues related with assessment are those that cause more problems for teaching staff. University level teaching is made more difficult because, in many cases, teachers do not have specialized training in the field of education and other related subjects, especially in topics related to assessment (Hawes, 2005). A good student can overcome poor quality teaching, but will find it much more difficult to overcome poor quality assessment. For most students, to a considerable extent, the assessment determines the curriculum: its selection, its content, its system for ranking priorities and its learning approach (James et al., 2002).

Curricular reforms oriented towards competence-based training include the problem of assessment, as would be expected with such a profound change from a framework based on objectives to one based on competences. Nevertheless, there is usually resistance to change, not only among teachers, but also among students for whom an assessment is only seen as such when it carries an associated grade (Hawes, 2005). An important aspect of this reform is related with the view of education as being focused both on the proposals set out for the subjects and, of equal importance, on the competency outcomes of the professional being trained. For this reason, there must be forward-looking management of the competences (Le Boterf, 2003).

The core question to be addressed is: What are the most effective ways for verifying if the students have achieved the competences required by the training course or programme? Assessment responds basically to the need for constructing, nurturing and using a student-centred system of institutional knowledge, with the ulterior motive of certifying and accrediting to society the professional quality of the graduate. Certainly, one prerequisite for a system of assessment, irrespective of the type, is that it must have a degree of credibility in the community at large.

For the knowledge management system to be relevant and able to activate the competences, it has to be envisaged as a process with the following clearly defined stages (Buck, 2003), see Figure 1. 


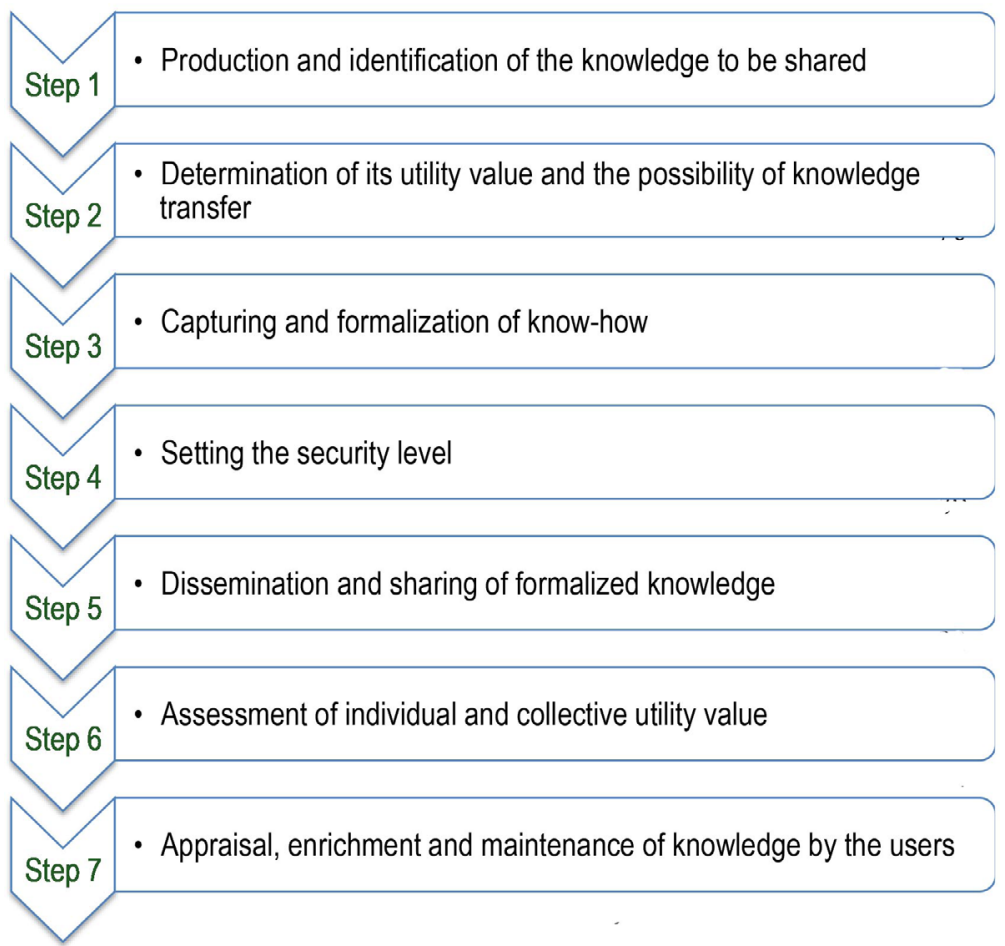

Figure 1. Management system by stages.

Analysing the usual practices that have been traditionally applied in higher education, it can be concluded that the first four stages are frequently completed, but the remaining three, which are more related to communication and sharing, are weakly structured (Hawes, 2005).

The UNE standard 66173 (2003) defines competence as those "personal attributes and (the) demonstrated ability to apply knowledge and skills"; specifically indicating that it is a synonym for "the ability to resolve problems in a certain context". Analysis of this regulation makes it possible to point out the following dimensions, which constitute the concept of competence and have to be considered in its assessment: a) Personal attributes or any attitude relating to the individual, that is, those characteristics that a person possesses from birth or has acquired by training, and that define who the person is (as against what the person does), such as: talent, motivation, communication skills, cognitive capacity, values, emotional intelligence and others, including knowledge ('to know') and abilities ('to know how'); b) Demonstrated aptitudes ('to do') that make up the observable behaviour as a response to the stimuli of a real life environment. It is an attempt to give precedence to what a person does (as against who the person is), that is, to the students' applied abilities and skills; and c) The demonstrated capacity to solve problems in any context; that capacity to be able to assume any foreknowledge and uncertainties derived from any environment in time (potential, available and required competences). All these dimensions can be summarized under the headings of 'being' (attitudes), 'knowing' (knowledge, approaches, theories) and 'know-how' (abilities).

The teaching staff needs instruments that facilitate the assessment of the results obtained by the student in achieving the competences in terms of these dimensions. In addition to the assessment criteria, defined by stating and detailing the particular competence, the following are needed: a) measurement scales that analyse objectively and are able to rank the learning outcomes; $b$ ) indicators that make it possible to compare, 
for each student, the real achievement for the competence with the pre-established level of knowledge and proficiency for this area of competence; and c) assessment techniques and methods that make it easier to obtain the data and information required -evidenceto be able to calculate the indicators (de la Mano González and Moro Cabero, 2009).

In the current university environment, focused on competence-based learning, this study tackles one of the most complex aspects of the training process: assessment. The aim of this study is to propose a measurement system, based on the use of rubrics, which allows the teaching staff to assess the achievement of competences by the student.

This study has two main objectives, to draw up the subject sheets on the basis of the competences included in the Accredited Degree Programme, and to carry out, for the first time, competence-based assessment of the subject.

Achievement of these objectives would also lead to achieving other sub-objectives:

- To clearly establish the specific competences of the subject on the basis of levels of acquisition.

- To develop a relevant competence-based assessment system that will provide their corresponding equivalences in the grading method used in our university system.

- To promote the acquisition of the specific competences of the subject, while simultaneously facilitating the acquisition of transversal competences, which allow the students to develop a series of professional competences related with the Analytical Chemistry from the earlier academic years of the Degree.

\section{Methods}

This study has been carried out during the first four-month period of the academic year 2010/2011 and has focused on the subject of Applied Analytical Chemistry (Basic level/ First four months) of the Pharmacy Degree that has 6 European Credit Transfer System (ECTS). This subject, taken in the $2^{\text {nd }}$ year of the degree, has been taught for the first time in the academic year 2010/2011. It has been implemented in 5 groups, with a total of 340 students, and with 9 lecturing staff involved. The staff had prior experience in different activities related with the implementation of the EHEA (European Higher Education Area) and with many of the new teaching methodologies (Asuero et al., 2006a; Asuero et al., 2006b; Asuero et al., 2007a; Asuero et al., 2007b; Asuero et al., 2008; Montaña et al., 2008; Galán et al., 2009; Herrador et al., 2009; Navas et al., 2009; Morales et al., 2010; Navas et al., 2010) which promote the acquisition of various competences, both transversal and specific, by the students.

As the subject in question is taught in the $2^{\text {nd }}$ academic year of the Degree, and the teaching staff had already taught other subjects to the same students in their $1^{\text {st }}$ academic year, the course started with the advantage that the students already knew the work methodology of the teaching staff. Most students had participated very actively in the innovation activities that had been carried out in the previous year, so that they were already receptive and participative.

The competences that were developed in this study are considered to be performance indicators for the pharmacist as analyst, so that those students who progress in their proficiency will have greater possibilities of practicing their profession with the appropriate knowledge, abilities and values. Therefore, to carry out this study the teaching staff analysed the concept and the elements that constitute the competence, 
as well as the different stages that its process of assessment entails. The final aim of this assessment process was no longer to determine the student's level of knowledge about specific thematic teaching blocks (Asuero et al., 2008), but rather to evaluate the student's level of proficiency for a specific competence.

When contemplating the teaching-learning process for competences, the teaching staff envisaged providing answers to a series of questions. A set of subject sheets about the competences were constructed, based on the course programme and according to the different thematic teaching blocks. They were structured following a basic pattern that makes it possible to give answers to the following questions: What to do?, How is it done?, Why is it done?.

The competences associated to each one of the thematic teaching blocks were selected. As they are competences specific to the subject, the proposals that define units of competence mainly include aspects related to 'knowledge' and to 'know-how'.

In this context, an evaluation rubric of the 10 main competences of the subject was produced, as an instrument to facilitate the assessment of the achievement of competence. Assessment of the competences assigned to each one of the thematic teaching blocks was structured according to the level of knowledge and abilities acquired, ranked from 4 (the maximum level) to 1 (the minimum level). For this study, assessment matrices or rubrics were used in which, in a phased and hierarchical way, the different levels of proficiency for the competence by the student were established, as well as the corresponding equivalences in the grading method used by our university system.

Once the rubric was created, it was implemented in the 5 course groups to assess the acquisition of competences, with a follow-up of the students throughout the fourmonth period. An opinion-satisfaction survey was also carried out. Finally, the grading was completed on the basis of acquisition of these competences.

The timetable followed for carrying out the study is shown in Table 1, which details the 6 phases for implementing the study during the four-month period.

\begin{tabular}{|c|c|c|c|c|c|c|}
\hline & September & October & November & December & January & February \\
\hline \multicolumn{7}{|l|}{$\begin{array}{l}\text { Phase } 1 \text {. Creation of subject } \\
\text { sheets based on competences. } \\
\text { Information to the students. }\end{array}$} \\
\hline \multicolumn{7}{|l|}{$\begin{array}{l}\text { Phase 2. Analysis and } \\
\text { selection of competences for } \\
\text { thematic teaching blocks. }\end{array}$} \\
\hline \multicolumn{7}{|l|}{$\begin{array}{c}\text { Phase } 3 \text {. Creation of } \\
\text { competence-based } \\
\text { assessment matrices. }\end{array}$} \\
\hline \multicolumn{7}{|l|}{$\begin{array}{l}\text { Phase 4. Application of } \\
\text { assessment matrices. }\end{array}$} \\
\hline \multicolumn{7}{|l|}{$\begin{array}{l}\text { Phase } 5 . \text { Information about } \\
\text { results to the students. } \\
\text { Opinion/satisfaction survey. }\end{array}$} \\
\hline $\begin{array}{l}\text { Phase } 6 \text {. Grading based on } \\
\text { the level of proficiency of the } \\
\text { competences. }\end{array}$ & & & & & & \\
\hline
\end{tabular}

Table 1. Timetable followed for carrying out the study 


\section{Results and discussion}

Six subject sheets were drawn up, one for each one of the thematic teaching blocks of the subject, in which the competences to be acquired by the student are specified in a simple manner, presenting them in a way that gives answers to the questions: What to do?, How is it done?, Why is it done?.

The first thematic teaching block (General Analytical Process, Sampling and Sample Preparation) includes three lectures about the general analytical process, as well as the study of sampling and sample preparation procedures. The competences corresponding to this block are shown in Table 2 .

\begin{tabular}{|c|c|c|}
\hline What to do? & How is it done? & Why is it done? \\
\hline $\begin{array}{l}\text { To carry out all the } \\
\text { stages of the general } \\
\text { analytical process, from } \\
\text { obtaining information } \\
\text { to drawing up the final } \\
\text { report. } \\
\text { To carry out the } \\
\text { appropriate sampling } \\
\text { and treatment of the } \\
\text { sample. }\end{array}$ & $\begin{array}{l}\text { Defining the analytical } \\
\text { problem. } \\
\text { - Choosing the most } \\
\text { appropriate method. } \\
\text { - Taking a representative } \\
\text { sample. } \\
\text { - Applying the optimized } \\
\text { treatment of the sample. }\end{array}$ & $\begin{array}{l}\text { To solve any analytical } \\
\text { problem in any area, with } \\
\text { different types of samples } \\
\text { and several analytes, using } \\
\text { the most appropriate } \\
\text { analytical method. }\end{array}$ \\
\hline
\end{tabular}

The second thematic teaching block (Chemometrics and Quality) consists of three lectures. The first one is aimed at understanding the variables that can affect the result obtained in the determination of an analyte, the second one covers the comparison procedures and chemometric tools necessary for such procedures, and the third one introduces the student to the importance of quality control in the analytical laboratory and how it is implemented. Table 3 shows the relevant competences assigned to this teaching block.

\begin{tabular}{|c|c|c|}
\hline What to do? & How is it done? & Why is it done? \\
\hline $\begin{array}{l}\text { Quality management } \\
\text { of the laboratory and } \\
\text { handling of the analytical } \\
\text { data to obtain quality } \\
\text { results. }\end{array}$ & $\begin{array}{l}\text { Treatment of analytical } \\
\text { data. } \\
\text { - Handling of chemometric } \\
\text { tools. } \\
\text { - Quality management and } \\
\text { the use of control cards. }\end{array}$ & $\begin{array}{l}\text { To know the variables } \\
\text { that can affect the } \\
\text { result obtained in the } \\
\text { determination of an } \\
\text { analyte in the laboratory. } \\
\text { - To be able to interpret } \\
\text { the data obtained in the } \\
\text { analysis. } \\
\text { To ensure the proper } \\
\text { functioning of the } \\
\text { laboratory. }\end{array}$ \\
\hline
\end{tabular}

The third block (Analytical Methods of Separation and Measurement) includes four lectures about the analytical methods of separation. An introduction to the topic is followed by coverage of the analytical procedures used in non-chromatographic separation and, subsequently, by two lectures focused on the chromatographic methods (gases, liquids and supercritical fluids). Table 4 shows the subject sheet of competences associated to this block.
Table 2. Subject sheet for the competences corresponding to the first thematic teaching block

Table 3. Subject sheet for the competences corresponding to the second thematic teaching block 


\begin{tabular}{|c|c|c|}
\hline What to do? & How is it done? & Why is it done? \\
\hline $\begin{array}{l}\text { To separate the } \\
\text { components of the } \\
\text { sample into different } \\
\text { fractions. }\end{array}$ & $\begin{array}{l}\text { By using non- } \\
\text { chromatographic } \\
\text { separation methods } \\
\text { (solvent extraction, } \\
\text { solid-phase extraction, } \\
\text { supercritical fluid } \\
\text { extraction, etc.) and } \\
\text { chromatographic ones } \\
\text { (planar chromatography, } \\
\text { of gases, of liquids, etc.). }\end{array}$ & $\begin{array}{l}\text { - To separate the analyte } \\
\text { from the rest of the } \\
\text { sample. } \\
\text { - To separate the } \\
\text { interfering species. } \\
\text { - To enrich the sample. } \\
\text { - To identify and quantify } \\
\text { analytes of a similar } \\
\text { composition and } \\
\text { structure. }\end{array}$ \\
\hline
\end{tabular}

The fourth block (Quantitative and Qualitative Aspects of Chemical Analysis) consists of two lectures about the quantitative and qualitative aspects of Analytical Chemistry, which give an overall view of both aspects of the chemical analysis. Table 5 shows the relevant competences for this thematic teaching block.

\begin{tabular}{|c|c|c|}
\hline What to do? & How is it done? & Why is it done? \\
\hline $\begin{array}{l}\text { To detect and quantify } \\
\text { the species in different } \\
\text { types of samples. } \\
\text { To generate numerical } \\
\text { data about the absolute } \\
\text { and relative quantities } \\
\text { of one or several } \\
\text { analytes of a sample. } \\
\text { To generate } \\
\text { information about the } \\
\text { presence or absence of } \\
\text { an analyte-species in } \\
\text { the sample. }\end{array}$ & $\begin{array}{l}\text { - Using screening } \\
\text { procedures, binary } \\
\text { answers, assigning of } \\
\text { false positives and false } \\
\text { negatives. } \\
\text { - Applying various analytical } \\
\text { quantification methods. } \\
\text { - Establishing the analytical } \\
\text { properties, carrying } \\
\text { out instrumental and } \\
\text { methodological calibration } \\
\text { and undertaking trace } \\
\text { analysis using reference } \\
\text { materials. } \\
\text { Evaluating the analytical } \\
\text { methods. }\end{array}$ & $\begin{array}{l}\text { To identify the analyte } \\
\text { from its chemical } \\
\text { and physicochemical } \\
\text { characteristics or by its } \\
\text { product reaction. } \\
\text { - To determine the content } \\
\text { of one or more analytes } \\
\text { of a sample. }\end{array}$ \\
\hline
\end{tabular}

The fifth thematic teaching block (Volumetric and Gravimetric Analysis) has a total of three lectures, in which are tackled the fundamentals and applications in the pharmaceutical area of volumetric methods, as well as those of gravimetric analysis. The competences assigned to this block are shown in Table 6 .

\begin{tabular}{|l|l|l|}
\hline \multicolumn{1}{|c|}{ What to do? } & \multicolumn{1}{c|}{ How is it done? } & \multicolumn{1}{c|}{ Why is it done? } \\
\hline To apply absolute and & $\bullet \begin{array}{l}\text { By using the analytical } \\
\text { balance and volumetric } \\
\text { stoichiometric methods }\end{array}$ & $\begin{array}{l}\text { To determine the major } \\
\text { material in the }\end{array}$ \\
$\begin{array}{l}\text { (gravimetric and } \\
\text { volumetric analysis) to }\end{array}$ & $\begin{array}{l}\text { development and } \\
\text { pharmaceutical interest. }\end{array}$ \\
$\begin{array}{l}\text { the determination of } \\
\text { analytes by weight and } \\
\text { volume. }\end{array}$ & $\begin{array}{l}\text { and volumetric analytical } \\
\text { methods. }\end{array}$ & \\
\hline
\end{tabular}

Table 4. Subject sheet for the competences corresponding to the third thematic teaching block

Table 5. Subject sheet for the competences corresponding to the fourth thematic teaching block

Table 6. Subject sheet for the competences corresponding to the fifth thematic teaching block 
Ten lectures of the course programme are dedicated to the sixth thematic teaching block (Trace and Instrumental Analysis), which also involves a high number of classroom hours. The lectures cover electroanalytical methods, optical methods, mass spectrometry and coupled methods, kinetic methods of analysis and immunoassay techniques, all topics of recognized interest in the field of health analysis. Table 7 shows the competences associated to this thematic teaching block of the course programme.

\begin{tabular}{|c|c|c|}
\hline What to do? & How is it done? & Why is it done? \\
\hline $\begin{array}{l}\text { - To carry out the } \\
\text { chemical measurement } \\
\text { process using (relative) } \\
\text { instrumental methods } \\
\text { that compare the signal } \\
\text { obtained from the } \\
\text { sample with those from } \\
\text { analytical standards. } \\
\text { - To apply analytical } \\
\text { procedures of special } \\
\text { interest in the } \\
\text { pharmaceutical field. }\end{array}$ & 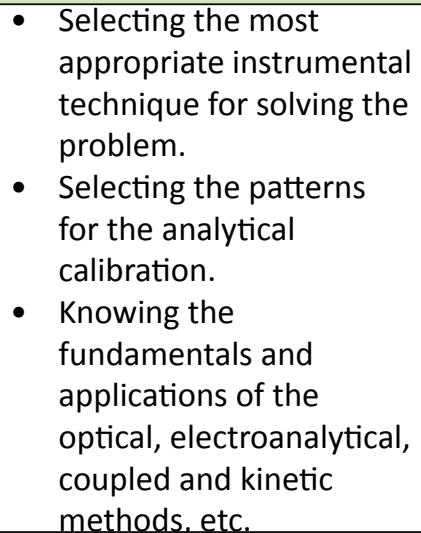 & 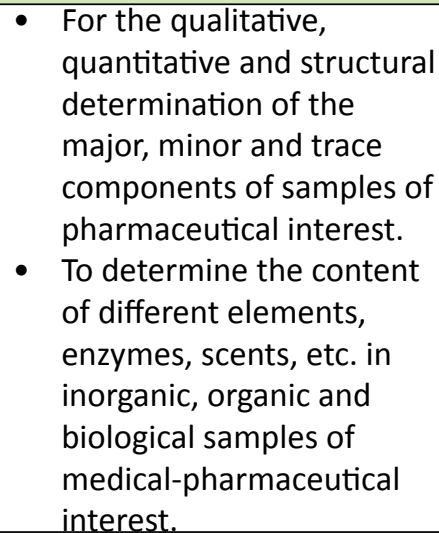 \\
\hline
\end{tabular}

Table 7. Subject sheet for the competences corresponding to the sixth thematic teaching block

Once the subject sheets for the different thematic blocks had been created, the competences related to each one of these blocks were selected, taking into account the knowledge and abilities that should be acquired by the students. An assessment rubric was designed that, by considering 10 specific competences of the subject, made followup possible for the abilities, knowledge and competences acquired by the students throughout the four-month period. As they are competences specific to the subject, the proposals that define its units of competence mainly include aspects related to these two dimensions of the competence: 'knowledge' and 'know-how'. The third dimension, 'the being' (the attitudes), was developed through the acquisition of transversal competences.

The procedure (de la Mano González and Moro Cabero, 2009; Delgado et al., 2005) that the teaching staff has followed for drawing up the evaluation rubric consisted of several stages:

- Analysis of the competences that are acquired from this subject, and of each one of the units of competence that define them, with the aim of identifying common elements in their formulation: the main actions (to know, to define, to apply, etc.) and the object of those actions (rules, terms, methodologies, etc.).

- Drawing up of general proposals from these common elements, with the aim of creating models of units of competence that can be applied to the particular context of each one of the specific competences.

- Classification of the proposals into two categories, 'to know', if they define actions related to the acquisition of knowledge, and 'to know how', if they define actions related to the application of practical abilities or skills. 
- Design of an individual scale for each unit of competence, constituted by four proposals that identify four different levels of proficiency of the competence (Blommel, 2007):

Level 1: the student does not make enough effort to acquire the competence and does not demonstrate having acquired it, or does so only rarely.

Level 2: the student studies, is trained and shows that he/she sometimes applies the competence.

Level 3: the student has learnt the competence, and by his/her performance demonstrates that he/she applies it.

Level 4: the student has integrated the competence into his/her pattern of performance.

- Integration of these scales for the units of competence into a general scale, organized around the four levels of the assessment system used in the university context of Spain (with their equivalences in the ECTS grading scale) (Table 8), which correspond to the levels of proficiency of the competence previously established (de la Mano González and Moro Cabero, 2009).

The result of this process has been the creation of an evaluation rubric for assessment of the competences of the course (Table 9), which has been designed so that: it can be easily applied; it can be verified objectively; and it is clearly understood by both the evaluators of the competences (the teachers), and by those who are going to be evaluated (the students).

\begin{tabular}{|c|c|c|}
\hline $\begin{array}{c}\text { Level of proficiency for } \\
\text { the competence }\end{array}$ & ECTS grading scale & Spanish grading system \\
\hline 1 & F / FX (Fail) & No Aprobado \\
\hline 2 & $\begin{array}{c}\text { E (Sufficient) } \\
\text { D (Satisfactory) }\end{array}$ & Aprobado \\
\hline 3 & C (Good) & Notable \\
\hline 4 & $\begin{array}{c}\text { B (Very good) } \\
\text { A (Excellent) }\end{array}$ & $\begin{array}{c}\text { Sobresaliente / } \\
\text { Matrícula de honor }\end{array}$ \\
\hline
\end{tabular}

Table 8. Equivalences between the grading scales and the levels of proficiency for the competence 


\begin{tabular}{|c|c|c|c|c|}
\hline COMPETENCE & 4 & 3 & 2 & \\
\hline $\begin{array}{l}\text { 1. To know the stages } \\
\text { of the overall analytical } \\
\text { process. To perform the } \\
\text { operations required for } \\
\text { sampling. To know how to } \\
\text { apply different operations } \\
\text { for sample treatment. }\end{array}$ & $\begin{array}{l}\text { Thorough knowledge } \\
\text { of the different phases } \\
\text { of the overall analytical } \\
\text { process. Very proficient } \\
\text { in the use of sampling } \\
\text { procedures and those of } \\
\text { the sample preparation }\end{array}$ & $\begin{array}{l}\text { Excellent knowledge of } \\
\text { the different phases of } \\
\text { the overall analytical } \\
\text { process. Applies the } \\
\text { procedures for sampling } \\
\text { and sample preparation. }\end{array}$ & $\begin{array}{l}\text { Acceptable level of } \\
\text { knowledge of the } \\
\text { different phases of the } \\
\text { overall analytical process. } \\
\text { Applies with difficulty } \\
\text { the sampling and sample } \\
\text { preparation procedures. }\end{array}$ & $\begin{array}{l}\text { Poor knowledge of } \\
\text { the different phases of } \\
\text { the general analytical } \\
\text { process. Shortcomings in } \\
\text { the implementation of } \\
\text { the sampling and sample } \\
\text { preparation procedures. }\end{array}$ \\
\hline $\begin{array}{l}\text { 2. To learn the basic } \\
\text { principles of statistics to } \\
\text { obtain quality analytical } \\
\text { results. To be able to } \\
\text { distinguish different types } \\
\text { of errors. To know how } \\
\text { to apply the statistical } \\
\text { criteria of significance to } \\
\text { a small data set. To know } \\
\text { how to use the criteria for } \\
\text { rejection of outliers. }\end{array}$ & $\begin{array}{l}\text { Thorough knowledge of } \\
\text { principles of statistics and } \\
\text { parameters indicative of } \\
\text { quality. Is able to handle } \\
\text { the statistical criteria of } \\
\text { significance for a small } \\
\text { data set. Uses the correct } \\
\text { criteria for rejection of } \\
\text { outlier data. }\end{array}$ & $\begin{array}{l}\text { Good knowledge } \\
\text { about the principles of } \\
\text { statistics and parameters } \\
\text { indicative of quality. } \\
\text { Fluent use of the } \\
\text { significance criteria for } \\
\text { a small data set. Applies } \\
\text { the appropriate criterion } \\
\text { for rejection of outlier } \\
\text { data. }\end{array}$ & $\begin{array}{l}\text { Acceptable level of } \\
\text { knowledge of the } \\
\text { principles of statistics and } \\
\text { parameters indicative of } \\
\text { quality. Applies with some } \\
\text { difficulty the criteria of } \\
\text { significance for a small } \\
\text { data set. Sometimes uses } \\
\text { the appropriate criterion } \\
\text { for rejection of outlier } \\
\text { data. }\end{array}$ & $\begin{array}{l}\text { Poor knowledge of the } \\
\text { principles of statistics and } \\
\text { parameters indicative } \\
\text { of quality. Shortcomings } \\
\text { in the application of the } \\
\text { criteria of significance } \\
\text { for a small data set. Does } \\
\text { not use the appropriate } \\
\text { criterion for rejection of } \\
\text { outlier data. }\end{array}$ \\
\hline $\begin{array}{l}\text { methodological calibration } \\
\text { procedures. To know how } \\
\text { to apply linear regression } \\
\text { to analytical data for } \\
\text { building and implementing } \\
\text { a calibration curve. }\end{array}$ & $\begin{array}{l}\text { Thorough knowledge } \\
\text { of the procedures } \\
\text { for methodological } \\
\text { calibration. Knows } \\
\text { how to apply linear } \\
\text { regression to analytical } \\
\text { data for building } \\
\text { and implementing a } \\
\text { calibration curve. }\end{array}$ & $\begin{array}{l}\text { Knowledge of the } \\
\text { procedures for } \\
\text { methodological } \\
\text { calibration. Knows } \\
\text { how to apply linear } \\
\text { regression to analytical } \\
\text { data for building } \\
\text { and implementing a } \\
\text { calibration curve. }\end{array}$ & $\begin{array}{l}\text { Acceptable level } \\
\text { of knowledge of } \\
\text { the procedures for } \\
\text { methodological } \\
\text { calibration. Sometimes } \\
\text { knows how to apply linear } \\
\text { regression to analytical } \\
\text { data for building } \\
\text { and implementing a } \\
\text { calibration curve. }\end{array}$ & $\begin{array}{l}\text { Poor knowledge } \\
\text { of procedures for } \\
\text { methodological } \\
\text { calibration. Does } \\
\text { not apply linear } \\
\text { regression to analytical } \\
\text { data for building } \\
\text { and implementing a } \\
\text { calibration curve. }\end{array}$ \\
\hline $\begin{array}{l}\text { 4. To know the principles } \\
\text { underlying the quantitative } \\
\text { volumetric and gravimetric } \\
\text { methods. To know the } \\
\text { differences between } \\
\text { them. To know how to } \\
\text { apply these methods } \\
\text { to the determination } \\
\text { of species of interest } \\
\text { in the pharmaceutical, } \\
\text { environmental and food } \\
\text { science fields. }\end{array}$ & $\begin{array}{l}\text { Thorough knowledge } \\
\text { of the quantitative } \\
\text { volumetric and } \\
\text { gravimetric methods. } \\
\text { Good command of the } \\
\text { differences between } \\
\text { them. Usually applies } \\
\text { these methods to the } \\
\text { determination of species } \\
\text { of interest. }\end{array}$ & $\begin{array}{l}\text { Knows the quantitative } \\
\text { volumetric and } \\
\text { gravimetric methods. } \\
\text { Knows their differences. } \\
\text { Applies in most cases } \\
\text { these methods to the } \\
\text { determination of species } \\
\text { of interest. }\end{array}$ & $\begin{array}{l}\text { Acceptable level of } \\
\text { knowledge of the } \\
\text { quantitative volumetric } \\
\text { and gravimetric methods. } \\
\text { Handles the differences } \\
\text { between them. } \\
\text { Occasionally applies } \\
\text { these methods to the } \\
\text { determination of species } \\
\text { of interest. }\end{array}$ & $\begin{array}{l}\text { Poor knowledge of the } \\
\text { quantitative volumetric } \\
\text { and gravimetric methods. } \\
\text { Has difficulty handling } \\
\text { the differences between } \\
\text { them. Does not apply } \\
\text { these methods to the } \\
\text { determination of species } \\
\text { of interest. }\end{array}$ \\
\hline $\begin{array}{l}\text { 5. To know how to perform } \\
\text { mathematical calculations } \\
\text { required for volumetric } \\
\text { and gravimetric analysis. To } \\
\text { know how to apply them } \\
\text { to solve practical cases of } \\
\text { pharmaceutical interest. }\end{array}$ & $\begin{array}{l}\text { Very proficient in the } \\
\text { mathematical calculations } \\
\text { required for volumetric } \\
\text { and gravimetric analysis. } \\
\text { Knows how to apply them } \\
\text { to solve practical cases of } \\
\text { pharmaceutical interest. }\end{array}$ & $\begin{array}{l}\text { Knows how to perform } \\
\text { the mathematical } \\
\text { calculations required } \\
\text { in the volumetric and } \\
\text { gravimetric analysis. } \\
\text { Usually knows how to } \\
\text { apply them to solve } \\
\text { practical cases of } \\
\text { pharmaceutical interest. }\end{array}$ & $\begin{array}{l}\text { Knows some of the } \\
\text { mathematical calculations } \\
\text { required for volumetric } \\
\text { and gravimetric analysis. } \\
\text { Occasionally applies } \\
\text { these calculations to } \\
\text { solve practical cases of } \\
\text { pharmaceutical interest. }\end{array}$ & $\begin{array}{l}\text { Poor knowledge of the } \\
\text { mathematical calculations } \\
\text { required for volumetric } \\
\text { and gravimetric analysis. } \\
\text { Does not apply these } \\
\text { calculations to solve } \\
\text { practical cases of } \\
\text { pharmaceutical interest. }\end{array}$ \\
\hline $\begin{array}{l}\text { 6. To know the principles } \\
\text { of the various non- } \\
\text { chromatographic } \\
\text { separation methods. To } \\
\text { be able to distinguish } \\
\text { between the different } \\
\text { procedures. To use } \\
\text { these methods to pre- } \\
\text { concentrate, condition } \\
\text { and/or separate analytes } \\
\text { for further analysis. }\end{array}$ & $\begin{array}{l}\text { Thorough knowledge } \\
\text { of the various non- } \\
\text { chromatographic } \\
\text { separation methods. } \\
\text { Distinguishes between } \\
\text { the different procedures. } \\
\text { Uses these methods } \\
\text { to pre-concentrate, } \\
\text { condition and/or separate } \\
\text { analytes for further } \\
\text { analysis. }\end{array}$ & $\begin{array}{l}\text { Knows the basics } \\
\text { of the various non- } \\
\text { chromatographic } \\
\text { separation methods. } \\
\text { Usually distinguishes } \\
\text { between different } \\
\text { procedures. In most } \\
\text { cases uses these } \\
\text { methods to pre- } \\
\text { concentrate, condition } \\
\text { and/or separate analytes } \\
\text { for further analysis. }\end{array}$ & $\begin{array}{l}\text { Knows some of the } \\
\text { non-chromatographic } \\
\text { separation methods. } \\
\text { Distinguishes with some } \\
\text { difficulty the different } \\
\text { procedures. Occasionally } \\
\text { applies these methods } \\
\text { to pre-concentrate, } \\
\text { condition and/or separate } \\
\text { analytes for further } \\
\text { analysis. }\end{array}$ & $\begin{array}{l}\text { Poor knowledge of } \\
\text { the various non- } \\
\text { chromatographic } \\
\text { separation methods. } \\
\text { Does not distinguish } \\
\text { between the different } \\
\text { procedures. Does not } \\
\text { apply these methods } \\
\text { to pre-concentrate, } \\
\text { condition and/or } \\
\text { separate analytes for } \\
\text { further analysis. } \\
\end{array}$ \\
\hline
\end{tabular}

Table 9

Evaluation

rubric

designed for competencebased assessment of the subject 


\section{To understand the}

fundamentals of different

chromatographic methods.

To know how to carry

out basic planar and

column chromatography

procedures. To identify

compounds in the

chromatograms. To

quantify compounds using

peak areas or heights.
Thorough knowledge

of the different

chromatographic

methods. Knows how to

perform basic planar and

column chromatography

procedures. Uses these

methods to identify

compounds in the

chromatograms. Applies

these techniques to

quantify compounds

using peak areas or

heights.

\section{Thorough knowledge}

of the basics of

the fundamentals of

electroanalytical methods

and their classification. To

know how to take direct

measurements of $\mathrm{pH}$,

conductivity and ESI. To

know how to detect the

end point of titrations

made by these methods. electroanalytical methods

and their classification.

Knows how to directly

measure $\mathrm{pH}$, conductivity

and ESI. Uses these

methods for detecting the

endpoint in titrations.
Knows the basics

of different

chromatographic

methods. Usually knows

how to perform basic

planar and column

chromatography

procedures. Uses

these methods for

the identification of

compounds in the

chromatograms. Usually

applies these techniques

to the quantification of

compounds using peak

areas or heights.

Has learnt the basics of

various electroanalytical

methods and their

classification. Usually

knows how to perform

direct measurements of

$\mathrm{pH}, \mathrm{ESI}$ and conductivity.

Usually applies theses

techniques to the

detection of the

endpoint of titrations.

Has learnt the

fundamentals and the

classification of optical

methods of analysis.

Usually knows the

differences between the

absorption and emission

processes. Usually

knows how to perform

the development of a

spectroscopic analytical method.

\section{Knows various methods}

of molecular and atomic

spectroscopy. Usually

knows how to apply

them to the analysis of

organic and inorganic

compounds.
Knows some of the

chromatographic

methods. Occasionally

knows how to perform

basic planar and column

chromatography

procedures. Uses with

difficulty methods to

identify compounds in

the chromatograms.

Applies these techniques

with difficulty to the

quantification of

compounds using peak

areas or heights.

Knows some of the

electroanalytical

methods and their

classification. Sometimes

knows how to take $\mathrm{pH}$,

ESI and conductivity

measurements directly.

Uses with difficulty these

methods to detect the

endpoint of titrations.
Poor knowledge

of the different

chromatographic

separation methods.

Does not know how to

perform basic planar and

column chromatography

procedures. Does not use

these methods to identify

compounds in the

chromatograms. Does not

apply these techniques

to the quantification of

compounds using peak

areas or heights.

Poor knowledge of

the fundamentals

of electroanalytical

methods and their

classification. Does not

know how to take $\mathrm{pH}$,

ESI and conductivity

measurements directly.

Uses with difficulty these

methods to detect the

endpoint of titrations.

Acceptable level of

knowledge of the

fundamentals and the

classification of optical

methods of analysis.

Sometimes knows the

differences between

the absorption and

emission processes.

Performs with difficulty

the development of a

spectroscopic analytical method.

\section{Acceptable level of}

knowledge of the various

methods of molecular

and atomic spectroscopy.

Sometimes knows how

to apply them to the

analysis of organic and

inorganic compounds.
Poor knowledge of the

fundamentals and the

classification of optical

methods of analysis. Does

not know the differences

between the absorption

and emission processes.

Is not able to perform the development of a spectroscopic analytical method.

Poor knowledge of the

various methods of molecular and atomic spectroscopy. Does not know how to apply them to he analysis of organic and inorganic compounds.
Table

9.(Continued)

\section{Conclusions}

The application of the rubrics to the performance of the students of the 5 course groups has made it possible to obtain relevant information regarding the following points: higher assessment of competences related to certain thematic teaching blocks; differences in inter- and intra-group assessments; the importance of ensuring that the different parts of the teaching methodology of the subject are not isolated sections, but that there is 
a relationship between all the teaching blocks and that to achieve the desired learning outcomes all parts have to be studied as a whole.

The training of the student is better when carried out in a context of professional competences rather than in a traditional way, because this approach enhances gradual learning of knowledge as well as of skills and abilities. For example, in a traditional way, students usually learn titrimetric methods studying the foundation and the titrimetric process itself. The approach to students of these methods as essential to solve real pharmaceutical analytical problems, which can found in their future professional development (pharmacopoeia analytical methods, pharmaceutical applications, etc.), increases the interest and curiosity of the students about the subject.

From the point of view of a student of pharmacy, it does not have the same interest to apply an acid-base titrimetric method to determine the concentration of any weak acid in any solution than to apply it to determine the concentration of acetylsalicylic acid in a tablet, for example.

The elements defined by the competences, which are shown in each one of the subject sheets, are the appropriate ones for ensuring that students achieve a better understanding of the analytical concepts necessary for their professional future. It is intended that the use of these competences introduces students to the real applications of Analytical Chemistry in the different career fields of the professional pharmacist. Within the profession, the future graduate would be able to pursue a career in companies or laboratories of different sectors, in which chemical or instrumental analyses are carried out to verify the quality level of the samples under analysis, or new analytical procedures are developed to respond to new situations, or to improve the efficiency and/or efficacy of the existing procedures.

The structuring of the competences based on the following questions: What to do?, How is it done?, Why is it done?, brings the academic world closer to the professional world, and facilitates a greater understanding and interest in the subject by the students.

The use of rubrics has made it possible to carry out competence-based assessment in a simple way. The most complex part of the process is the selection of the appropriate competences for the creation of assessment matrices. However, this stage has the advantage that it requires the teaching staff to carry out an in-depth analysis not only of the course content for the subject, but also of the abilities and skills to be imparted to the student in the training to ensure the acquisition of competence.

This new form of assessment is a tool that allows the teacher to know where there are gaps in student learning, and this information can be used to prioritize the training of those skills later in the teaching-learning process of each student. Another advantage of this assessment system is that it clearly shows the weaknesses in the teacher's knowledge transfer system and, therefore, is a useful tool for detecting the most critical points that require the implementation of methods for improvement and, thereby, to ensure the acquisition of skills and competences by the students.

\section{References}

Asuero, A. G. Galán, G. Herrador, M. A. Jiménez, A. M. Montaña, M. T. Morales, M. T. Navas, M. J. Sayago, A. (2006a). Diseño de un plan de innovación docente para la mejora del aprendizaje. Jornadas Nacionales de Intercambio de Experiencias Piloto de Implantación de Metodologías ECTS. Badajoz: Serv. Publicaciones y Oficinas de Convergencia Europea de la UEx., pp. 1-38. 
Asuero, A. G. Galán, G. Herrador, M. A., Jiménez, A. M. Montaña, M. T. Morales, M. T. Navas, M. J. Sayago, A. (2006b). Ficha de la asignatura "Análisis Químico" de la Facultad de Farmacia de Sevilla: Experiencia piloto de créditos europeos. Jornadas Nacionales de Intercambio de Experiencias Piloto de Implantación de Metodologías ECTS. Badajoz: Serv. Publicaciones y Oficinas de Convergencia Europea de la UEx., pp. 1-86.

Asuero, A. G. Galán, G. Herrador, M. A. Jiménez, A. M. Montaña, M. T. Morales, M. T. Navas, M. J. (2007a). Incorporación de la Materia Troncal "Análisis Químico" a la Experiencia Piloto para la implantación del Crédito Europeo en Andalucia: Implementación de Nuevas Actividades. II Jornadas Nacionales de Metodologías ECTS. Badajoz: Serv. Publicaciones y Oficinas de Convergencia Europea de la UEx., pp. 1-166.

Asuero, A. G. Galán, G. Herrador, M. A. Jiménez, A. M. Montaña, M. T. Morales, M. T. Navas, M. J. (2007b). Vertebración de la Enseñanza de la materia troncal Análisis Químico de la Licenciatura de Farmacia en base a competencias. II Jornadas Nacionales de Metodologías ECTS. Badajoz: Serv. Publicaciones y Oficinas de Convergencia Europea de la UEx., pp. 1-167.

Asuero, A. G. Galán, G. Herrador, M. A. Jiménez, A. M. Montaña, M. T. Morales, M. T. Navas, M. J. (2008). Teaching analytical chemistry by a competency-based approach. Pharmacy Education, 8, 69-102.

Blommel, M. L. Abate, M. A. (2007). A rubric to assess critical literature evaluation skills. The American Journal of Pharmaceutical Education, 71, 1-8.

Buck, J. Y. (2003). Le Management des Connaissances et des Compétences en pratique. Paris: Éditions d'Organisation.

De la Mano González, M. Moro Cabero, M. (2009). La evaluación por competencias: propuesta de un sistema de medida para el grado en Información y Documentación. Bid textos universitaris de biblioteconomia i documentació, 23, 1-16.

Delgado, A. Borge Bravo, R. García Albero, J. Oliver Cuello, R. Salomón Sancho, L. (2005). Competencias y diseño de la evaluación continua y final en el espacio europeo de educación superior. Barcelona: Ministerio de Educación y Ciencia.

Galán, G. Montaña, M. T. (2009). Aprendizaje basado en problemas como herramienta de innovación docente en la asignatura Análisis Químico. XV Reunión de la Sociedad Española de Química Analítica, San Sebastián: SEQA., p. 1-33.

Hawes, B. G. (2005). Evaluación de competencias en la educación superior. Chile: Instituto de Investigación y Desarrollo Educacional, Universidad de Talca (Chile).

Herrador, M. A. Morales, M. T. (2009). El congreso virtual como herramienta de aprendizaje en Química Analítica. XV Reunión de la Sociedad Española de Química Analítica, San Sebastián: SEQA. p. 54.

James, R. Mclnnis, C. Devlin, M. (2002). Assessing learning in Australian universities. Melbourne: The University of Melbourne, Centre for the Study of Higher Education.

Le Boterf, G. (2003). Ingénierie et Évaluation des Compétences. Paris: Éditions d'Organisation.

Montaña, M. T. Asuero, A. G. Galán, G. Herrador, M. A. Jiménez, A. M. Morales, M. T. Navas, M. J. (2008). Modificación de la metodología educativa para la mejora del aprendizaje del Análisis Químico. Edusfarm, revista d'educació superior en Farmàcia, 3, 1-18. 
Morales, M. T. Herrador, M. A. Galán, G. Montaña, M. T. Hernanz, M. D. Jiménez, A. M. Navas, M. J. Asuero, A. G. (2010). Iniciativa interdisciplinar y de enfoque transversal en la enseñanza de la Química Analítica. ARS Pharmaceutica, 50, 269-278.

Navas, M. J. Jiménez, A. M. Asuero, A. G. Galán, G. Herrador, M. A. Montaña, M. T. Morales, M. T. (2009). La plataforma virtual WebCT en la enseñanza de la disciplina Análisis Químico en la licenciatura de Farmacia: evaluación de la actitud del alumnado. Edusfarm, revista d'educació superior en Farmàcia, 5, 1-12.

Navas, M. J. Jiménez, A. M. Montaña, M. T. Hernanz, M. D. Asuero, A. G. Herrador, M. A. Galán, G. Morales, M. T. (2010). Resolución de casos prácticos en pequeños grupos en la enseñanza de la asignatura Química General y Analítica del grado en Farmacia. ARS Pharmaceutica, 50, 96-101.

Poloyac, S. M. Empey, K. M. Rohan, L. C. Skledar, S. J. Empey, P. E. Nolin, T. D. Bies, R. R. Gibbs, R. B. Folan, M. Kroboth, P. D. (2011). Core Competencies for Research Training in the Clinical Pharmaceutical Sciences. The American Journal of Pharmaceutical Education, 75, 1-9.

Ríos Muñoz, D. Herrera Araya, D. (2018). The challenges of competence-based assessment in the educational field. Educação e Pesquisa 43, 1073-1086.

UNE 66173 2003. Gestión de las competencias. Los recursos humanos en un sistema de gestión de la calidad. Gestión de las competencias.

Recepción: 27 de julio de 2018. Aprobación: 27 de noviembre de 2018 